\title{
BUSINESS SUSTENANCE IN AFRICAN ENTREPRENEURSHIP
}

\author{
Dr. Krishnan Umachandran ${ }^{1}$
}

\begin{abstract}
Entrepreneurship in Africa is a complex environment different from their other parts of the world. Linking product and services direct to the customer as an integrated business process needs to be very innovative to meet the requirement in line with economy and offer a degree of flexibility that other competitors cannot offer. The impact of massive technological discoveries and innovations is now felt in Africa; however, entrepreneurs are unaware to devote their resources towards sustainability and growth. Key words - Entrepreneurship, Business Sustainability, Africa, Technology, Organization
\end{abstract}

\section{INTRODUCTION}

Tim Brown, CEO of IDEO quoted that whether it is a startup entrepreneur or corporate entrepreneur, there are important lessons for the quest toward the new and unknown. Sustainable entrepreneurship (in Africa is a complex environment different from their other parts of the world right from physical aspects of life (terrains, food, hygiene), infrastructural development (water, electricity, telecommunications), socio-cultural (regional, clan orientation grouping) should be focused to preserve and nurture the life as a community in the pursuit of perceived opportunities to bring in future products, processes and services for gain

\section{ENTREPRENEURSHIP}

Entrepreneurship is a career that can offer a degree of flexibility that some other careers do not offer. The impact of massive technological discoveries and innovations is now felt in Africa; however, entrepreneurs are unaware to devote their resources towards sustainability and growth. Productivity in a business environment needs to be disciplined. The negatives in culture should be processed immediately and will have no place in the organization, which will impact upon the productivity. Disciplined human resources tuned to the learning curve is one of the vital connect which needs to be timely tapped by organizations.

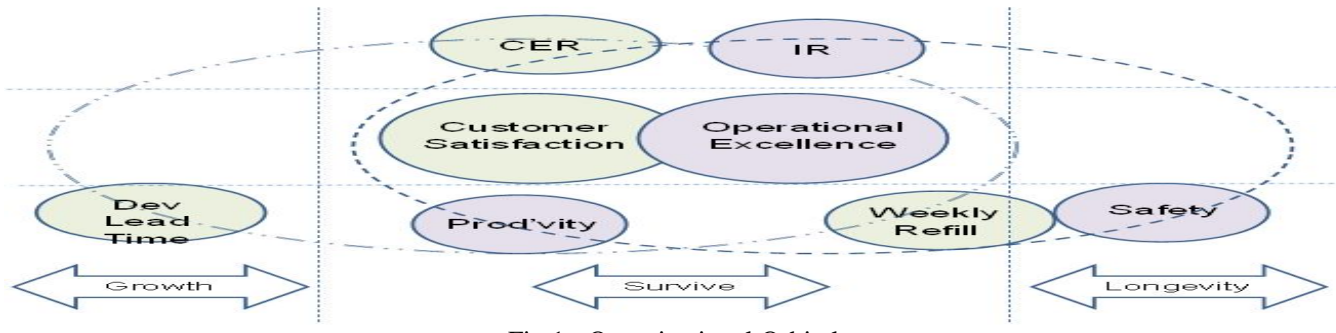

Fig 1 - Organizational Orbitals

Source - Krishnan Umachandran (2014)

1 General M anager - Org Dev (Nelcast Ltd.); Prof - PM IR, M SSW, India (earlier lived in East African Countries carrying out Technology business \& taught in M akerere University, Uganda.) 


\section{AFRICAN ENTREPRENEURSHIP}

Late coming, excuses, unauthorized absence, dereliction of duty, unauthorized control and mishandling of money and organizational resources are important and needs to be controlled right from policy evolution. Analyzing and implementing corrective actions are necessary steps towards the economic wellbeing of the enterprise, in all stages of organizational life (early, revival, growth and safety); which creates enormous amount of pressure on the Entrepreneur. The brainstorming team for entrepreneurial need identification should comprise of an experienced group of people who can provide vital contributions with social consciousness to build sustainable business enterprises in various stages of businesses. The process need should be innovative to meet the survival requirement and later to apply appropriate interventions in line with economy, wherein today even existing organizations are looking towards a turn around. Despite very minimal competition among African natives in the local markets, the global space is intense with synergization. Every vertical, be it pharmaceutical, financials, manufacturing, technology, education and recreation the market is open inviting the cutting edge delivers to prosper leaving others to survive. They need to seriously engage in the business and take necessary measures and actions to ensure capitalization on the opportunities.

\section{Six conventional boundaries of competition}

Six Paths Framework

- Industry

- Strategic Group

- Customer Group

- Scope of Product or

Service Offering

- Fucntional-emotional

Orientation

- Time
Normal Strategy

Blue Ocean Strategy

The global economy is recovering from the onslaught of recession. Experienced with earlier recession cycles of business, entrepreneurs adopt discretionary fiscal and frugal monetary policies to co-exist with their customers and suppliers. Building local ecosystems of vendors, suppliers and community as customer require investment in capacity building and training such as in direct marketing, SIM card sellers, water can distributors and home services etc. There is a significant demand on the role of the African entrepreneur to the business, depending upon the details of business, regional-bilateral trade partnerships and settings, industrial and economic productivity ambience, and firm practice targets the dynamics of business. Some businesses which are late to realize and change suffer with the failing economy or tough situations can panic with anxiety and unemployment. Entrepreneurs need polycentric attitudes to understand, and consider every opportunity to learn and develop and successfully deal the reality. The opportunity to course correct lays cold after a wide and comprehensible over-run of "time and impact". Linking product and services direct to the customer as an integrated process is facilitated with internet technologies. Intervention alleviating red tape and other barriers during start up gets vanished in times of economic crises, leaving entrepreneurs to swim the turbulence on their own. Preempting these situations, they need to cautiously prune their activities to be highly dependable and create surpluses during the normal operations. 


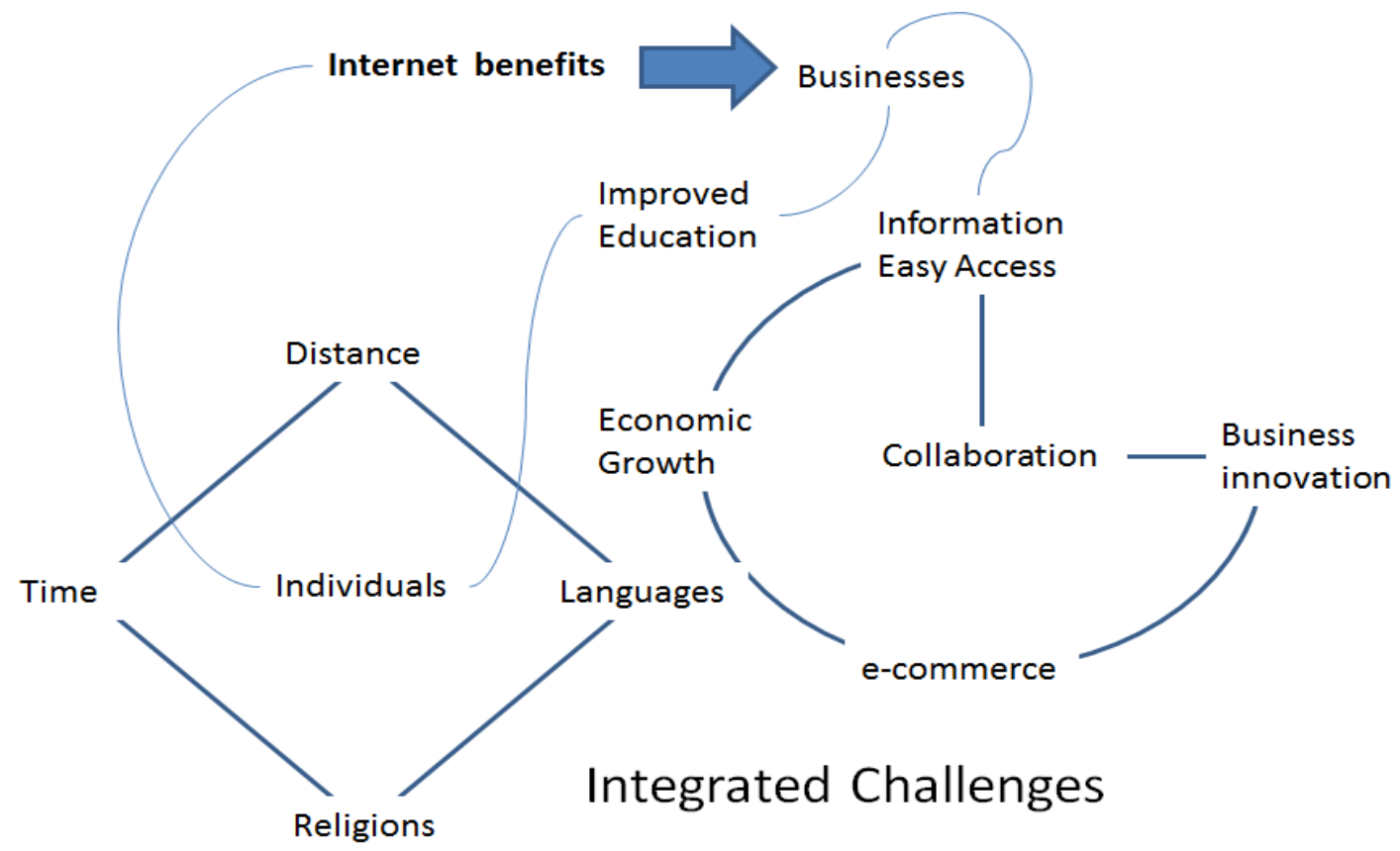

Fig 3 - Integrated Challenges in Business Collaborations Source - Krishnan Umachandran (2015)

Boundaries of competition are segregated as Industry, Strategic Group and Customer Group on Product or Service Offering, through Functional-emotional Orientation circumference by time. The financial fund flow requires concentration for upscale implementations in establishing SME clusters for sustainable development states that the United Nations Industrial Development Organization (UNIDO) defines industrial cluster as "geographic and economic concentration of manufacturing activities which produce and sell a domain of interrelated and complementary products and having common problems and opportunities".

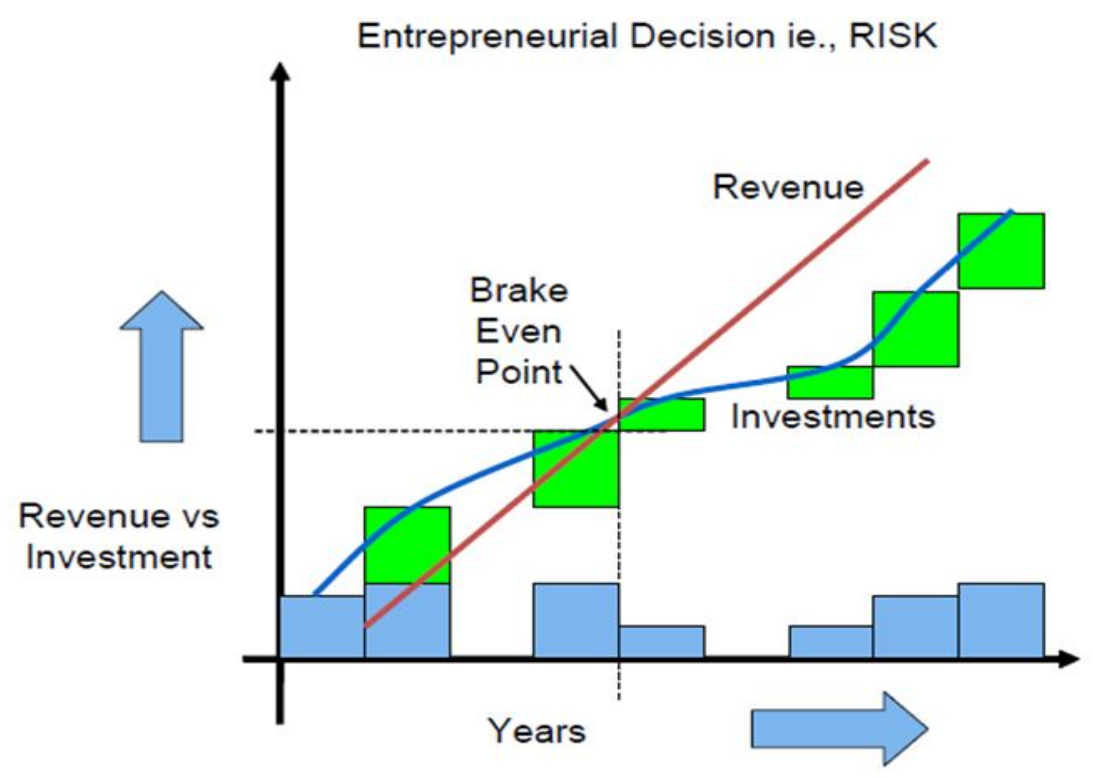

Fig 4 - Risk of Entrepreneurial Decisions Source - Krishnan Umachandran (2015) 
Founding families will continue to retain significant shares of the company, thereby seeking new opportunities related or new to the present line of operations, introduction of new products and brands ahead of competition, strategically can eliminate operations which are declining in the life cycle. Similar proactivity in committing a relatively large portion of assets, and borrowing heavily requires a heavy determination of the entrepreneur to position the business for an escalation ahead of the competition. Trading has improved economy in Africa and interaction among countries and continents results in more of exports and imports, however the need for customers are not utilized properly for their development. Western cultural influences have a tremendous impact on the African economy more, leading to demand on Cars as a symbol of wealth among educated youth. The banks lure these people offering loans towards the luxury of life products than on to the basics such as housing, health and education, that would eventually drive them to sustainable comfort. However, the need for servicing and replacement vehicle components and long-haul / all-terrain commercial vehicles, agricultural and industrial equipment, furniture and household machines and ICT products have a great requirement in Africa. Regulations and structural reformations right from budgetary support is the need of every African country that which can support the entrepreneurial development. Once the business chain picks up the country can be at peace and development shall happen. To enable such, the ruling governments need to have an eye on the economy on a long-term initiative. Fly-by-night product qualities and underrated goods should be inspected and stopped right even before it finds its way into the country, through proper licensed and regulated imports. Change in people attitude-perception-motivation, should be towards a healthier lifestyle. Learning on-the-job is inevitable in business, appropriate training programmes are required to complement the learning from experience. An orientation to employees even before induction is a must to tune them for a business mode. A well-developed cross functional team can be a breakthrough for entrepreneurial support. In business, as diverse groups must be dealt, socially intelligent employees are required to quickly assess the emotions and adapt words, tone and gestures to collaborate, build trust relationships and cooperate with groups of people in different settings.

\section{Teams Improve Competitive Advantage}

1. Cost Reduction Team

2. Waste Reduction Team

3. Rejection Control Team

4. Productivity Improvement Team

5. Quality Circle Teams

6. Small Group Activities (SGAs)

7. Cross Functional Teams (CFTs)

8. Task Forces

9. Project Implementation Teams
Technology Update

Resource Utilisation

ROCE

$\mathrm{ROI}$

Process Adherence

Employee Engagement

Skill enhancement

Process wastages

Idleness

Inventory

Grievance

Attrition

\section{Good Manufacturing Practices (GMP)Teams}

Fig 5 - Competitive Advantage of Teams Source - Krishnan Umachandran (2015) 
Employees who represent the entrepreneur, need to be accurate in perceiving others positively, for financial success of entrepreneur. To remain competitive, work need to be carried out in teams, wherein a collective effectual reasoning may have upon the 'success' of the entrepreneurial process. Conflict and creativity in the management work teams is essential to combat competition. As it creates uncertainty, high commitment situation demands conflicting perspectives to positively impact team performance. Strategic planning of Manpower costs depends on age, education level, functional background heterogeneity, team demography; environmental complexity, environmental instability and demanded performance. In addition, the indirect cost of living and compensations, Electricity and Health care, Taxes and Other Statutory Payments are important components in Operating costs which impacts the bottom-line of the organization. Hence all the resources coordinated needs to perform optimally for providing continuous and reliable business. Optimizing resource utilization can be achieved through improvements in several factors including: environmental conditions, consumer usage behavior, utilities specifications etc. Review of the resource management modeling and simulation, highlights good achievements possible in the future as it identifies many directions and gaps for a better system to be evolved and developed.

\section{Entrepreneurial Intelligent Systems}

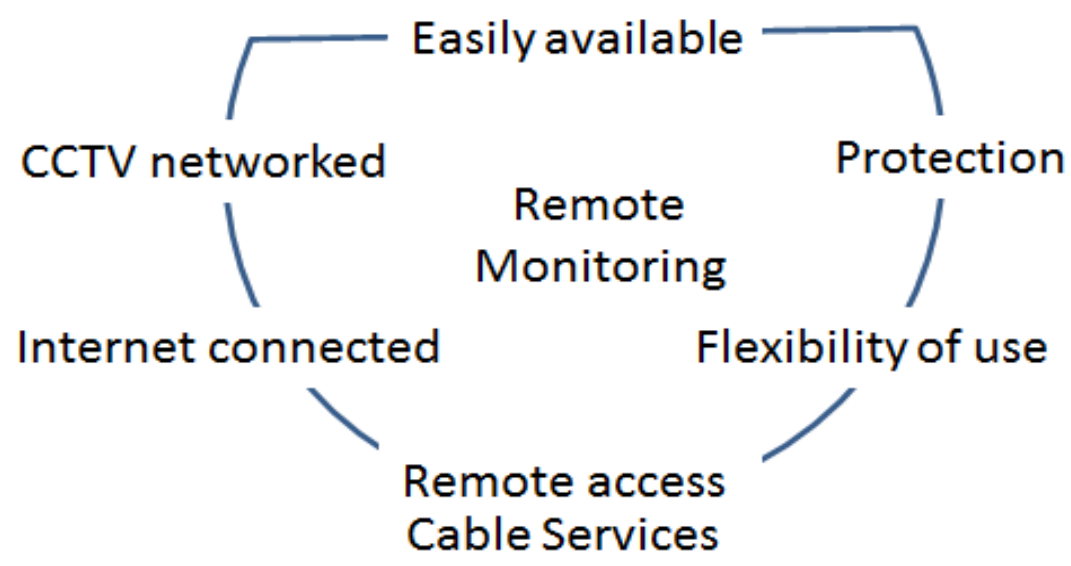

Fig 6 - Entrepreneurial Intelligence System Source - Krishnan Umachandran (2015)

\section{IV.CONCLUSION}

To imbibe in them the quantification of the economy, performance, emissions/wastes or degradation of utilities using alternative technologies, modifying to suit existing with the co-positioning of hybrid configurations, maximizing revenues, minimize costs, along with cost-cutting measures to increase operational efficiency, production capacity should continue prominence in the organization's Long-term strategic actions, is more of a syllabus to them. Therefore nurturing them to fulfill a sustainable business of an African entrepreneur is time drawn, system centered and requires vigilante timely accounting of business.

\section{REFERENCES}

1. Dalin, S. (2005) "Increasingly blacks also become entrepreneurs", Houston Chronicle, Texas, October 24, page.5.

2. Jeremy C. Short, G. Tyge Payne, Keith H. Brigham, G. T. Lumpkin, J. Christian Broberg (2011), "Family Firms and Entrepreneurial Orientation in Publicly Traded Firms A Comparative Analysis of the S\&P 500", Family Business Review Volume 22 Number 1 March 2009 9-24, Family Firm Institute, Inc. 10.1177/0894486508327823, Sage Publication.

3. Loury, Glenn C. 2008. "Is He One of Us?' Reflections on Identity and Authenticity." The 2008 Opening Convocation Address Brown University, September. 
4. Md. Joynal Abdin (2015), "Establishing SME clusters for sustainable development, SME Foundation (National Agency for SME Development)", Bangladesh, DEPARTMENT - Planning, Monitoring and Evaluation

5. Mengsteab Tesfayohannes (2012), "African entrepreneurs should plan and aspire beyond the fence at the current complex global business environment", Sigmund Weis School of Business, Susquehanna University, Selinsgrove, PA, USA

6. Ndubuisi Ekekwe (2016), "Why African Entrepreneurship is booming?" Harvard Business Review, Entrepreneurship.

7. Richardson, P., Howarth, R. and Finnegan, G. (2004), "The challenges of growing small businesses: insights from women entrepreneurs in Africa". IFP/SEED Working Paper No. 47, Series on Women's Entrepreneurship Development and Gender Equality (WEDGE), ILO, Geneva.

8. Saskia Vossenberg (2016), "Gender-Aware Women's Entrepreneurship Development for Inclusive Development in Sub-Saharan Africa", Include, Knowledge platform on inclusive development policies, Gender Advisory and Knowledge Services, Netherland.

9. Scott E. Page (2008), "The Difference: How the Power of Diversity Creates Better Groups, Firms, Schools and Societies". Princeton: Princeton University Press.

10. Singh, G. and Belwal, R. (2008) "Entrepreneurship and SMEs in Ethiopia: evaluating the role, prospects and problems faced by women in this emergent sector", Gender in management: An International Journal,23(2), 120-136.

11. Strategic Research and Innovation Agenda 'Vision 2023', Food Technology Platform food for life

12. Swithina Mboko, Andrea Smith-Hunter, "Zimbabwe Women Business Owners: Survival Strategies and Implications for Growth", Journal of Applied Business and Economics vol.11(2), http://www.na-businesspress.com/JABE/Jabe112/SmithHunterWeb.pdf

13. Tjosvold, D. (2008) “The conflict-positive organization: it depends upon us”, Journal of Organizational Behavior, Vol. 29, No. 1, pp.1928.

14. Umachandran.K (2015), "Blue Ocean Marketing Leaders", Research Gate

15. UN-INSTRAW (nd) "Glossary of gender related terms and concepts". UN International Research and Training Institute for the Advancement of Women

16. Vossenberg, S. (2013) "Women entrepreneurship promotion in developing countries: what explains the gender gap in entrepreneurship and how to close it?”, Maastricht School of Management Working Paper Series, (2013/08). 